\title{
Development and Evaluation of Cleaner cum Pearler for Finger Millet
}

\author{
V.V. Tejaswini*, D. Bhaskara Rao, R. Lakshmipathy and Sivala Kumar \\ Processing and Food Engineering, ANGRAU, Bapatla, India \\ *Corresponding author
}

\begin{tabular}{|l|}
\hline Ke y w or d s \\
Finger millet (Eleusine \\
coracona), Ragi
\end{tabular}

\section{A B S T R A C T}

Finger millet (Eleusine coracona), popularly known as Ragi, has high yield potential of greater than $10 \mathrm{t} / \mathrm{ha}$ under optimum irrigated conditions. Usually millet seeds have four layers namely hull, bran, germ and endosperm. Among these, endosperm is only the edible part of millet. Bran and germ are rich in oil and hence affect the storage quality of millets. So dehulling / pearling of finger millet is necessary to remove the hull, bran and germ to increase the shelf life of the pearled grain and flour. In traditional dehulling, the grain is mixed with water, allowed to stand for 5 minutes and pounded with a wooden pestle for 10-15 minutes. Then grains are subjected to drying and then winnowing operation to remove the bran and other fine material. The pounding and winnowing processes are repeated several times till the good quality millet is obtained. The most rustic equipment for cleaning is the winnower fan, air blowers etc., this operation is time consuming, laborious and uneconomical to the farmers. Therefore, there is a need to develop a suitable small scale cleaner cum pearling unit for finger millet so that the pearling losses can be reduced and it can be useful for farmers with small land holdings. The developed cleaner cum pearler for finger millet machine consisted of cleaning unit, hopper, and outer cylinder, inner cylinder with 12 cotton felts $(10 \times 10 \times 1 \mathrm{~cm})$ with one end of them bolted on its surface, main frame, aspirator $(0.5 \mathrm{hp})$ and electric motor $(2.5 \mathrm{hp})$. The cleaning unit consisted of stainless steel plate with circular perforations of $2 \mathrm{~mm}$ diameter which works on the principle of vibration through which the cleaned grains goes into pearling unit which consists of inner and outer cylinders. The clearance between cylinders was $2 \mathrm{~cm}$ and $1 \mathrm{~cm}$ at cotton felts for maximum compression and shearing of grains so that the grains get pearled. Pearled grain enter into closed outlet at the middle of which a pipe from the aspirator was fixed so that the husk and other lighter particles were collected by suction and cleaned, pearled grains were collected at the other end of the outlet. The cleaning efficiency of the machine was $88.2 \%$. The performance of the machine was tested for its pearling efficiency, percentage of broken grain at speeds 1400, 900, 500, $300 \mathrm{rpm}$; moisture contents $10,13,16 \%$ (w.b) and at feed rates $90,120,150 \mathrm{~kg} / \mathrm{h}$ for two passes. The pearling efficiency decreased with increase in moisture content and increased with the increase of cylinder speed and feed rate. The percentage of broken grain decreased with the increase in moisture content and feed rate and increased with increase in cylinder speed. The highest percentage of broken grain was found to be $9.5 \%$ at $10 \%$ w.b moisture content, $1400 \mathrm{rpm}$ at $90 \mathrm{~kg} / \mathrm{h}$ (II pass). The optimum value of pearling efficiency was 80.1 $\%, 4.3 \%$ of broken grain at $10 \%$ w.b moisture content, $900 \mathrm{rpm}$ at $150 \mathrm{~kg} / \mathrm{h}$ feed rate (II pass). 


\section{Introduction}

Finger Millet (Eleusine coracona) popularly known as Ragi, is originally native to the Ethiopian highlands. It was introduced into India approximately 4000 years ago. It is highly adaptable to higher elevations and is grown in the Himalayas up to an altitude of $2300 \mathrm{~m}$. It is the most important small millet in the tropics (12\% of global millet area) and is cultivated in more than 25 countries in Africa (eastern and southern) and Asia (from Near East to Far East), predominantly as a staple food grain. The major producers are Uganda, India, Nepal, and China. Finger millet has high yield potential (>10 t/ha under optimum irrigated conditions). India contributes $55 \%$ of total world production. Finger millet is especially valuable as it contains the amino acid methionine, which is lacking in the diets of hundreds of millions of the poor who live on starchy staples such as cassava, plantain, polished rice, or maize meal. Finger millet can be ground and cooked into cakes, puddings or porridge. The grain is made into a fermented drink (or beer) in Nepal and in many parts of Africa. The straw from finger millet is used as animal fodder. Finger millet is nutritionally superior to rice and wheat. These are rich in protein, mineral, vitamins and contain higher proportion of dietary fiber than rice or wheat.

Usually millet seeds have four layers namely hull, bran, germ and endosperm. Among these, endosperm is only the edible part of millet. The hull contains mainly indigestible fibers. Due to the presence of outer layer in finger millet the flour colour is black and taste is also not good due to presence of bitterness. Bran and germ are rich in oil and hence affect the storage quality of millets. So dehulling / pearling of finger millet are necessary to remove its outer layer to improve its flour quality. Finger millet is variable in shape, size and colour. It may be elliptical, oblanceolate, hexagonal or globular in shape. Finger millet grains are smaller in size with $1.2-1.7 \mathrm{~mm}$ diameter. The colour of seed coat of the millet varies from dark red to purple, but brick red is the most common colour. The endosperm and seed coat accounting for about $85 \%$ and $13 \%$ of seed mass, respectively whereas the embryo forms only $1-2 \%$ of it. Pearling of finger millet is usually done at a moisture content of $10 \%$. In the process of pearling, it is necessary to remove the hull, bran and germ to increase the shelf life of the pearled grain and flour. In traditional dehulling, the grain is mixed with water, allowed to stand for 5 minutes and pounded with a wooden pestle for 10-15 minutes.

Then grains are subjected to drying and then winnowing to remove the bran and other fine material. The pounding and winnowing processes are repeated several times till the good quality millet is obtained. This operation is time consuming, laborious and uneconomical to the farmers. Keeping this in view a suitable small scale cleaner cum pearling unit for finger millet (Eleusine coracana) was developed and evaluated for its performance so that the pearling losses can be reduced and it can be useful for farmers with small land holdings.

\section{Materials and Methods}

\section{Description of various parts of the machine}

\section{Cleaning unit}

The hexagon shaped frame consisted of a perforated stainless steel sheet at the top and plane sheet fixed to a frame so that the grains that pass through the perforations fell on the bottom plate and then into the hopper. The circular perforations were of $2 \mathrm{~mm}$. The particles greater than the grain size remains on the top and the grains along with some fine dust and foreign particles fell into the hopper. 
Later those fine dust and foreign particles were removed by aspiration. This whole frame was mounted with help of springs on a frame which was welded on the outer cylinder at an angle of $27^{\circ}$. A cam like arrangement was made between the shaft and sieve so that it is vibrated along with the rotation of the shaft.

\section{Hopper}

The hopper was fabricated in trapezoidal shape, using mild steel of 18 gauge thickness and dimensions of $20 \mathrm{~cm}$ length, $12.5 \mathrm{~cm}$ width and $22 \mathrm{~cm}$ height. It is placed on the outer cylinder at one end.

\section{Outer cylinder}

The outer cylinder was made of 16 gauge mild steel sheet of $40 \mathrm{~cm}$ diameter and $80 \mathrm{~cm}$ length. One side of the cylinder is open and fixed with a circular plate of $48 \mathrm{~cm}$ diameter so that inner cylinder and shaft assembly can be easily accommodated. The pearled grain moved towards the outlet at the end of outer cylinder which had a circular perforations of $1 \mathrm{~cm}$ diameter so that the grain get discharged slowly through them and fell on the closed outlet. The outer cylinder was welded to the main frame of the machine.

\section{Inner cylinder}

The inner cylinder was made of high carbon steel of $34 \mathrm{~cm}$ diameter and $60 \mathrm{~cm}$ length having cotton felts (12 Nos.) which were made of several layers of tough cotton fibres similar to material of cotton belts used for conveying with $10 \mathrm{~cm}$ length, $10 \mathrm{~cm}$ width and $1 \mathrm{~cm}$ thick on it.

They were bolted to the drum such that 2 felts and 1 felt alternatively with a distance of $5 \mathrm{~cm}$ alternatively. Hence there was a clearance of 2 $\mathrm{cm}$ between the cylinders and $1 \mathrm{~cm}$ where the cotton felts are present. One end of the cotton felt was left free so that it can increase the shearing on the grains by carrying round the rotation and increases the percentage of pearling. It was mounted on a power shaft at its centre.

\section{Shaft}

The solid power shaft was made of mild steel of $3.8 \mathrm{~cm}$ diameter and $140 \mathrm{~cm}$ length. It was supported at the end on the main frame by UCP208 pillow block bearings. It is powered by motor by means of V-belt pulley arrangement.

\section{Outlet and aspirator}

The outlet was a closed arrangement and made of mild steel at the middle of which a pipe from the aspirator was fixed so that the husk and other lighter particles are collected by suction. An aspirator of $0.5 \mathrm{hp}$ power was used for suction of husk and other foreign material from the pearled grains. The area of cross section of the pipe of the aspirator at the suction end was $113.09 \mathrm{~cm}^{2}$ and at the outlet pipe was $50.26 \mathrm{~cm}^{2}$. The velocity of air through the pipe was about $2 \mathrm{~m} / \mathrm{s}$ hence the air flow rate was $0.025 \mathrm{~m}^{3} / \mathrm{s}$. The air flow rate was controlled by adjustable gate at the air flow according to the feed rate for better performance. This was concluded based the terminal velocity of the grains.

\section{Main frame}

The metal frame which made of (L) angle iron was fabricated in a trapezoidal shape of 82.5 $\mathrm{cm}$ front top width, $76 \mathrm{~cm}$ bottom width, 25 $\mathrm{cm}$ side top width, $27 \mathrm{~cm}$ side bottom width and $75 \mathrm{~cm}$ high were welded to the sides of the outer cylinder so that the weight of the whole assembly was balanced and vibrations were minimized. The motor and the electric aspirator motor were also mounted at the bottom of the main frame. 


\section{Power Transmission}

A 3 phase, $2.5 \mathrm{hp}$ motor was used for giving motion to shaft and inner cylinder through belt drive. The belt drive consists of $\mathrm{V}$ belt and pulley. The driver pulley of $12.7 \mathrm{~cm}$ (5 in) was mounted on the motor and the driven pulley of required diameter $(13,20.3,36.5 .60 .9 \mathrm{~cm})$ as per the required speed $(1400,900,500,300$ rpm) was mounted on the shaft. The variation in the speeds was taken to know the results at low speeds also.

As the motor was switched on the driver pulley rotates this motion is transferred to the driven pulley which in turn rotates the shaft and the inner cylinder and the grains get pearled. A $0.5 \mathrm{hp}$ aspirator was used for aspiration of husk, dust and other lighter foreign materials.

\section{Design of pulley size}

The size of the pulley can be specified by the diameter of the pulley. It can be determined by the following formula

$\frac{\mathbf{N}_{1}}{\mathbf{N}_{2}}=\frac{\mathbf{D}_{2}}{\mathrm{D}_{1}}(1)$

$\mathrm{N}_{1}=$ Speed of the driver pulley (rpm) (motor pulley); $\mathrm{D}_{1}=$ Diameter of the driver pulley (rpm) (motor pulley)

$\mathrm{N}_{2}=$ Speed of the driven pulley (rpm) (shaft pulley); $\mathrm{D}_{2}=$ Diameter of the driven pulley (rpm) (shaft pulley)

\section{Length of the belt}

Length of the V- belt for different sizes of the pulleys was obtained from the following formula

$$
L_{b}=\frac{\pi}{2}\left(d_{1}+d_{2}\right)+2 x+\frac{\left(d_{2}-d_{1}\right)^{2}}{4 x}
$$

$L_{b}$ is pitch length of belt $(\mathrm{cm}) d_{l}$ is diameter of pulley mounted at motor $(\mathrm{cm})$

$d_{2}$ is diameter of pulley mounted at shaft $(\mathrm{cm})$ $x$ is distance between centres of pulleys $(\mathrm{cm})$

\section{Power required driving the pulley}

$\mathrm{P}_{1}=2^{\pi} \mathrm{NT}_{1}(3)$

Torque $\mathrm{T}_{1}=\mathrm{m} \times \mathrm{g} \times \mathrm{D} / 2$

$\mathrm{m}=$ mass of smaller pulley attached to the belt drive

$\mathrm{D}=$ Diameter of smaller pulley attached to the belt drive

$\mathrm{N}=$ Speed of pulley

Power required for driving the shaft and cylinder of pearler unit

$\mathrm{P}_{2}=2^{\pi} \mathrm{NT}_{2}(4)$

$\mathrm{T}_{2}=$ Torque to drive the shaft

$\mathrm{T}_{2}=$ Total weight on the shaft $\mathrm{x}$ Radius of the driven pulley

$=(w t$ of the cylinder + wt of the pulley) $\mathrm{x}$ Radius of the driven pulley

\section{Design of shaft diameter}

Based on the design of the machine horizontal mild steel solid shaft was used. The shaft was subjected to combined twisting and bending moment. Considering the load of cylinder acts at the centre of the shaft. Loads on shaft may be represented by following diagram:

Force acting at point $\mathrm{C}$ by the weight of the pulley (weight of $60.9 \mathrm{~cm}$ pulley was taken). The bending load comprises of horizontal and vertical components. The resultants of the 
bending moments at point $\mathrm{C}$ and point $\mathrm{D}$ were calculated by horizontal and vertical load diagrams. The maximum value was taken as bending moment at that point $\mathrm{M}_{\mathrm{b}}$.

Torque transferred by the shaft $\mathrm{M}_{\mathrm{t}}=\frac{P \times 60}{2 \pi \mathrm{N}}(5)$

Therefore the diameter of the shaft given by

$\mathrm{d}^{3}=\frac{16\left[\left(K_{b} M_{b}\right)^{2}+\left(K_{t} M_{t}\right)^{2}\right]^{1 / 2}}{\pi \times S_{S}}$

Ss = allowable combined shear stress for bending and torsion for steel shaft without keyway

$=55 \mathrm{MPa}$

$K b=$ combined shock and fatigue factor applied to bending moment $=1.5-2.0$ for minor shock.

$K t=$ combined shock and fatigue factor applied to torsional moment $=1.0-1.5$ for minor shock.

Performance evaluation of cleaner cum pearler for finger millet

The developed cleaner cum pearler for finger millet was evaluated for combination of different moisture contents i.e., 10, 13, $16 \%$ at different feed rates i.e., 90, 120, $150 \mathrm{~kg} / \mathrm{h}$ and at different cylinder speeds i.e., 300, 500, $900,1400 \mathrm{rpm}$. The performance of the machine was evaluated based on its cleaning efficiency, pearling efficiency and percentage of broken grain.

\section{Cleaning efficiency}

The cleaning efficiency is given by the following formula.

Cleaning efficiency $(\%)=\frac{\mathrm{E}(\mathrm{F}-\mathrm{G})(\mathrm{E}-\mathrm{F})(1-\mathrm{G})}{\mathrm{F}(\mathrm{E}-\mathrm{G})^{2}(1-\mathrm{F})}$
$\mathrm{E}=$ Fraction of clean seed at clean seed outlet

$\mathrm{F}=$ Fraction of clean seed in feed

$\mathrm{G}=$ Fraction of clean seed at foreign matter outlet (aspirator outlet + sieve outlet)

\section{Pearling efficiency}

The pearling efficiency was given by the following formula (IS: 9555 - 1980).

$$
\begin{aligned}
& \text { Pearling efficiency } \\
& \text { Weight of the pearled grain } \\
& =\text { Weight of the feed } \times 100(8)
\end{aligned}
$$

\section{Percentage of broken grain}

The percentage of broken grain was given by the following formula.

Percentage of broken grain $(\%)=$ Weight of the broken pearled grain at oulet

Total weight of pearled grain obtained at outlet $\times 100$

\section{Results and Discussion}

\section{Design of pulley size}

The motor of $1440 \mathrm{rpm}\left(\mathrm{N}_{1}\right)$ was used and the diameter of the motor pulley was $12.7 \mathrm{~cm}$ $\left(D_{1}\right)$.The required speeds for testing the machine were 1400, 900, 500, $300 \mathrm{rpm}$. Hence by using above equation (1) the required diameter of the pulleys for 1400, 900, 500, $300 \mathrm{rpm}$ speeds were obtained as $13 \mathrm{~cm}(5.1$ in), $20.3 \mathrm{~cm}$ (8 in), $36.5 \mathrm{~cm}$ (14 in), $60.9 \mathrm{~cm}$ (24 in) respectively (Fig. 1-6).

\section{Length of the belt}

Length of the V-belt for different sizes of the pulleys was obtained from the equation (2)

$d_{l}$ is diameter of pulley mounted at motor $(\mathrm{cm})=12.7$ 
$d_{2}$ is diameter of pulley mounted at shaft $(\mathrm{cm})$ $=13,20.3,36.5$ and 60.9

$x$ is distance between centers of pulleys $(\mathrm{cm})=$ 44.1

By using the equation (2) pitch length of the belts were obtained as $128.56 \mathrm{~cm}, 140.36 \mathrm{~cm}$, $168.69 \mathrm{~cm}, 216.98 \mathrm{~cm}$.

Hence the belts of B45, B52, B62, B80 available in the market were used.

\section{Power required driving the pulley}

$\mathrm{P}_{1}=2^{\pi} \mathrm{NT}_{1}$

Torque $\mathrm{T}_{1}=\mathrm{m} \times \mathrm{g} \times \mathrm{D} / 2$

$\mathrm{m}=$ mass of smaller pulley attached to the belt drive $=1.5 \mathrm{~kg}$

$\mathrm{D}=$ Diameter of smaller pulley attached to the belt drive $=0.13 \mathrm{~m}$

$\mathrm{N}=$ Speed of pulley

$\mathrm{T}_{1}=1.5 \times 9.81 \times 0.065=0.956 \mathrm{~N}-\mathrm{m}$

$\mathrm{P}_{1}=2 \times{ }^{\pi} \times 1400 \times 0.956 / 60=140.2 \mathrm{~W}=$ $0.18 \mathrm{hp}$

Power required for driving the shaft and cylinder of pearler unit

$\mathrm{P}_{2}=2^{\pi} \mathrm{NT}_{2}$

$\mathrm{T}_{2}=$ Torque to drive the shaft

$\mathrm{T}_{2}=$ Total weight on the shaft $\mathrm{x}$ Radius of the driven pulley

$=(\mathrm{wt}$ of the cylinder $+\mathrm{wt}$ of the pulley) $\mathrm{x}$ Radius of the driven pulley

$=(78.48 \mathrm{~N}+19.62 \mathrm{~N}) \times 0.065 \mathrm{~m}=6.37 \mathrm{~N}-\mathrm{m}$
$\mathrm{P}_{2}=2 \times \pi \times 1400 \times 6.37 / 60=933.89 \mathrm{~W}=$ $1.25 \mathrm{hp}$

Total power required $=0.18+1.2=1.43 \mathrm{hp}$

Factor of safety 1.5 was considered as different loads are used then,

Power $=1.5 \times 1.43=2.14 \mathrm{hp}$

The available motor in market is $1.5 \mathrm{hp}, 2 \mathrm{hp}$, $2.5 \mathrm{hp}$ etc.

Hence, a motor of $2.5 \mathrm{hp}$ was selected to drive the machine

\section{Design of shaft diameter}

From the figure 1, the bending moments at different points on the shafts are calculated as follows

Resultant bending moment at point $\mathrm{C}=9.920$ $\mathrm{N}-\mathrm{m}$

Resultant bending moment at point $\mathrm{D}=$ $35.250 \mathrm{~N}-\mathrm{m}$

Therefore the maximum bending moment is at point $\mathrm{D}, \mathrm{M}_{\mathrm{b}}=35.250 \mathrm{~N}-\mathrm{m}$

Torque transferred by the shaft was given by the Equation (5) $\mathrm{M}_{\mathrm{t}}=\frac{P \times 60}{2 \pi \mathrm{N}}$

$\mathrm{P}=$ power of the motor $=2.5 \mathrm{hp}=1.865 \mathrm{~kW}$, $\mathrm{N}=1400 \mathrm{rpm}$

Hence $\mathrm{M}_{\mathrm{t}}=12.72 \mathrm{~N}-\mathrm{m}$

Therefore the diameter of the shaft was given by Equation (6)

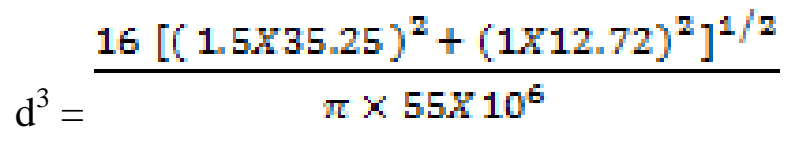


Fig.1 Schematic representation of load acting on the shaft

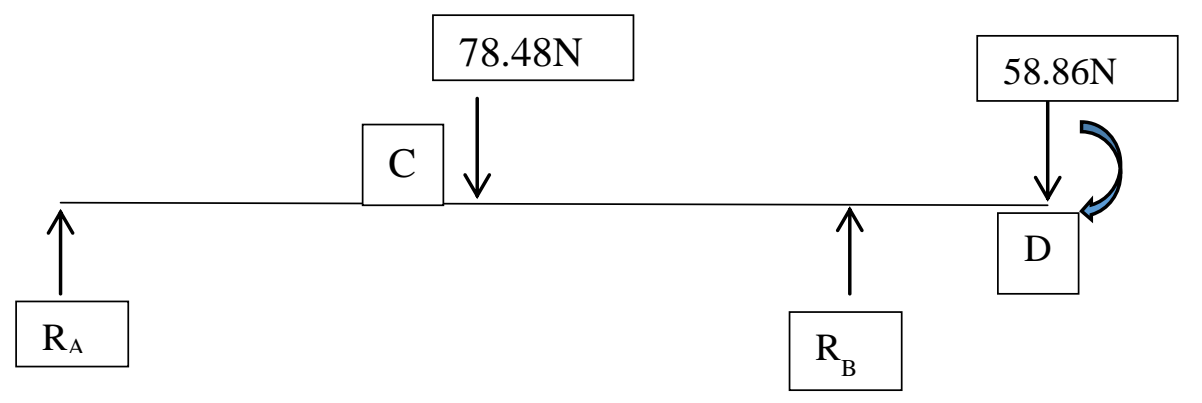

Fig.2 Front view of power operated cleaner cum pearler for finger millet

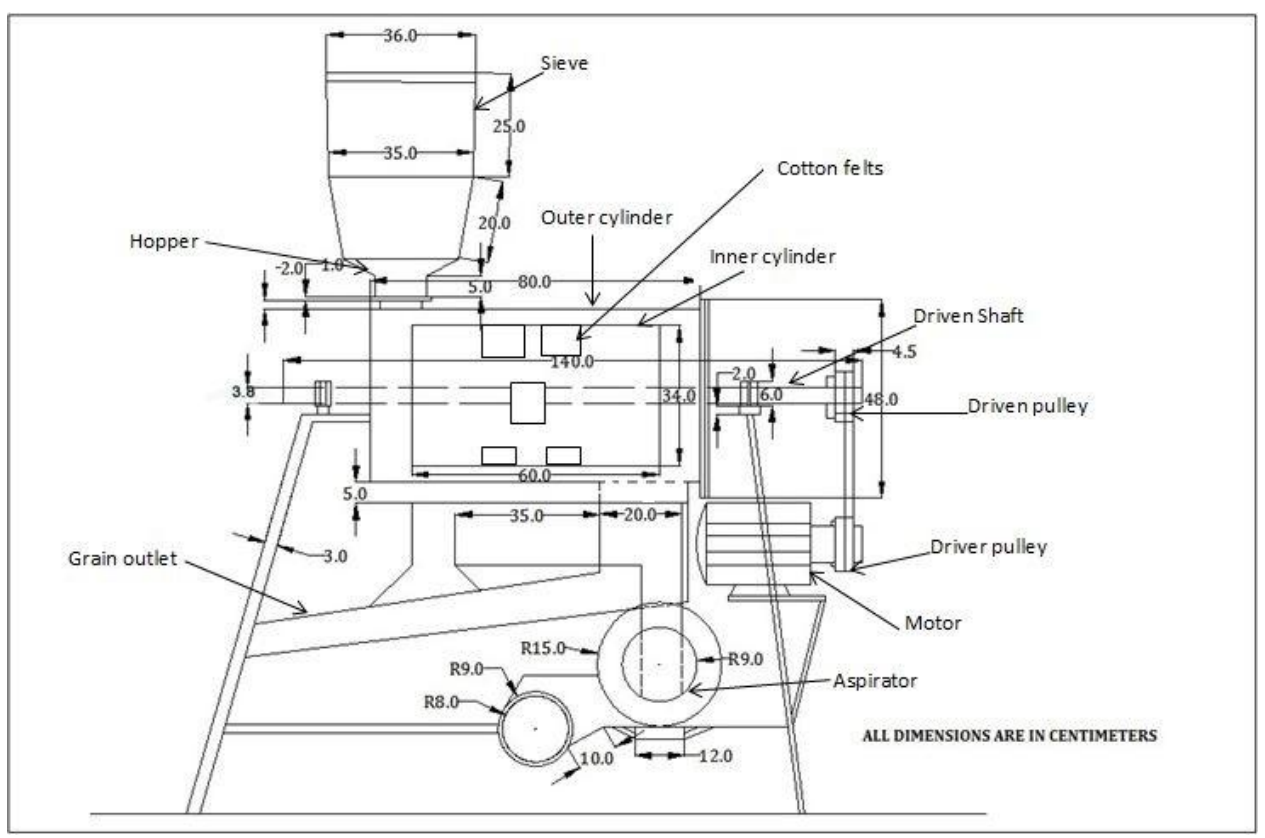

Fig.3 Top and Side view of power operated cleaner cum pearler for finger millet
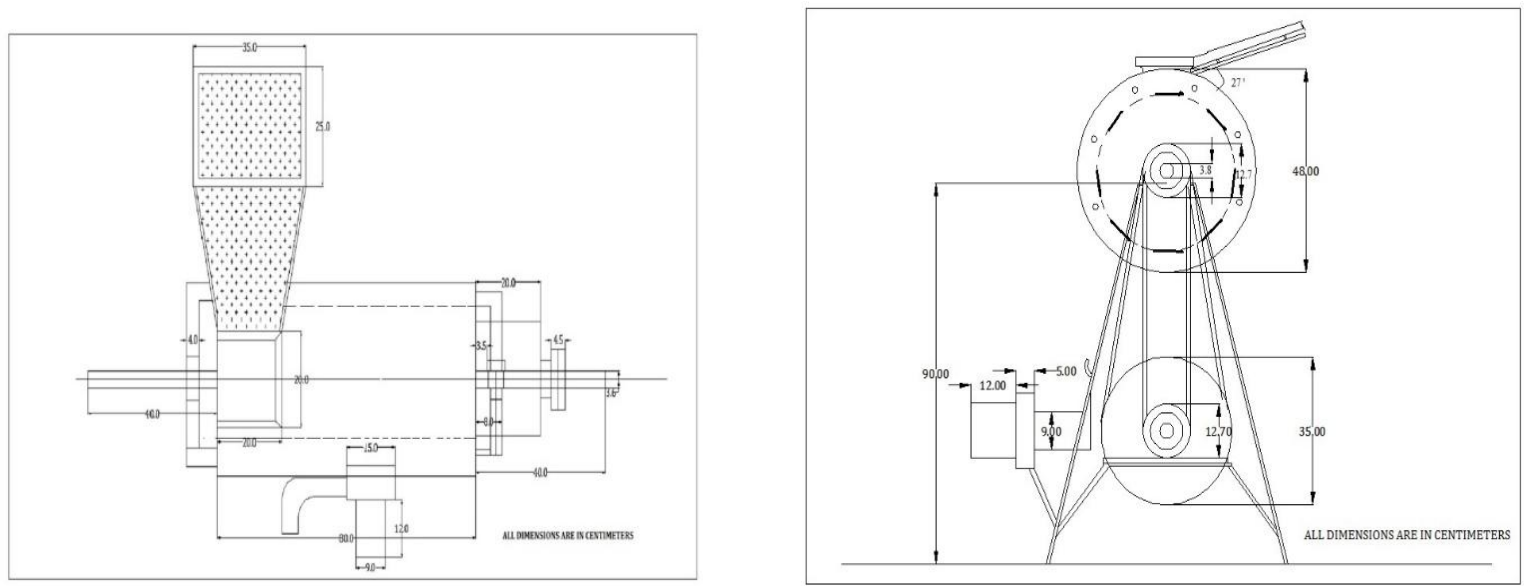
Fig.4 Variation of pearling efficiency with moisture content and speed of cylinder at feed rate of $90 \mathrm{~kg} / \mathrm{h}$

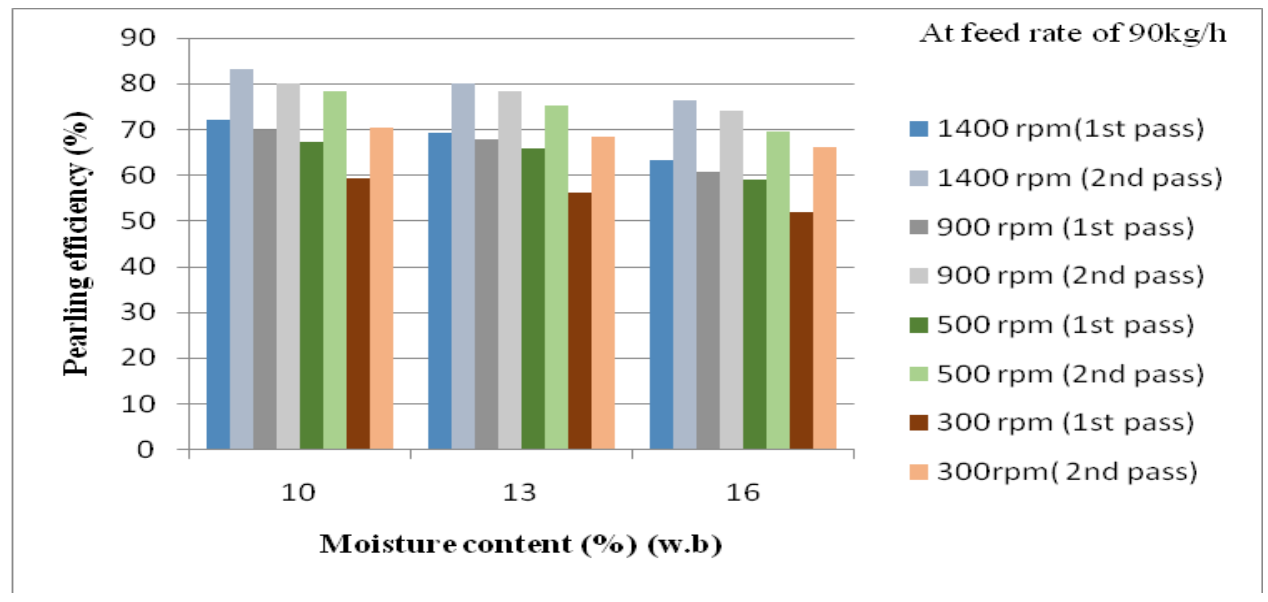

Fig.5 Variation of pearling efficiency with moisture content and speed of cylinder at feed rate of $120 \mathrm{~kg} / \mathrm{h}$

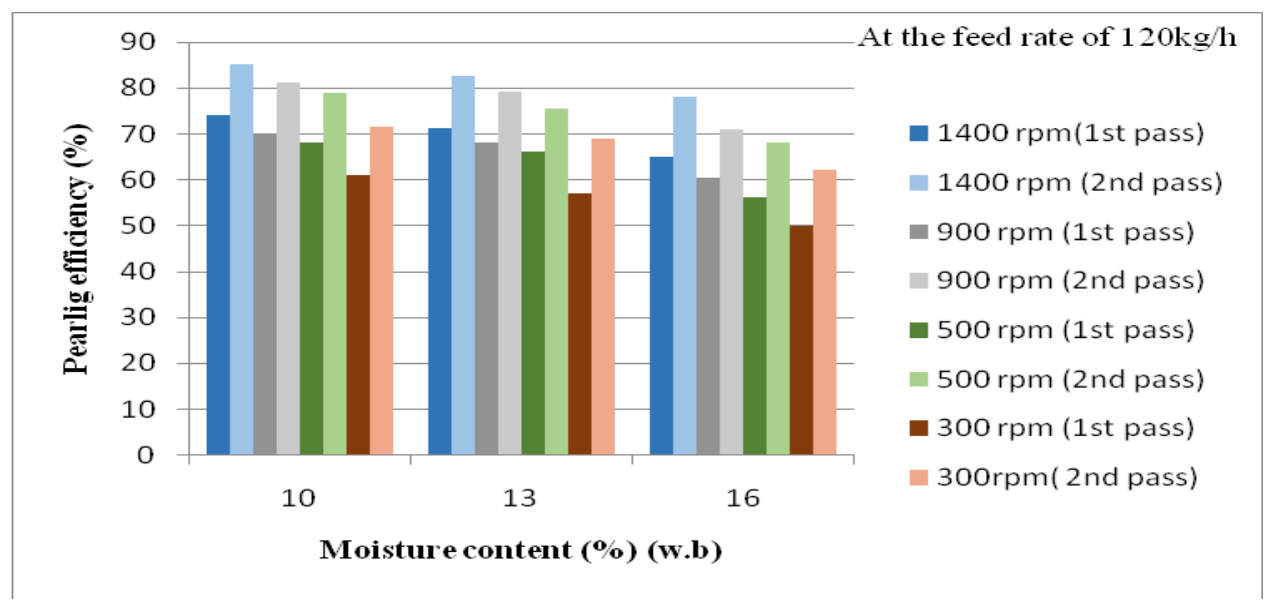

Fig.6 Variation of pearling efficiency with moisture content and speed of cylinder at feed rate of $150 \mathrm{~kg} / \mathrm{h}$

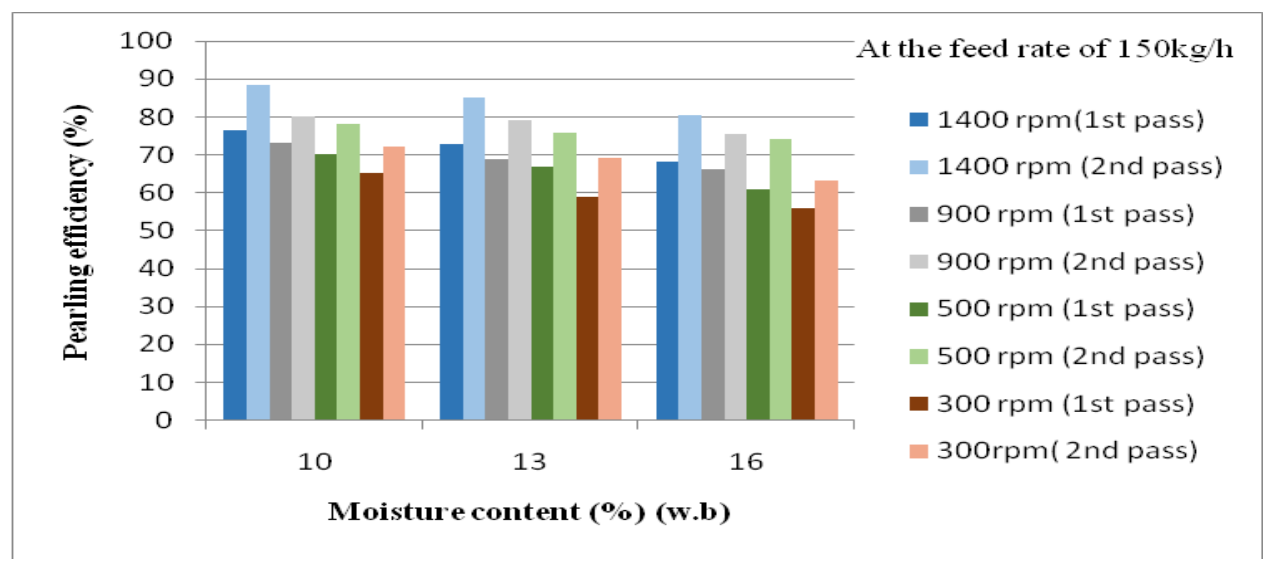


Fig.7 Variation of percentage of broken grain with moisture content and speed of cylinder at feed rate of $90 \mathrm{~kg} / \mathrm{h}$

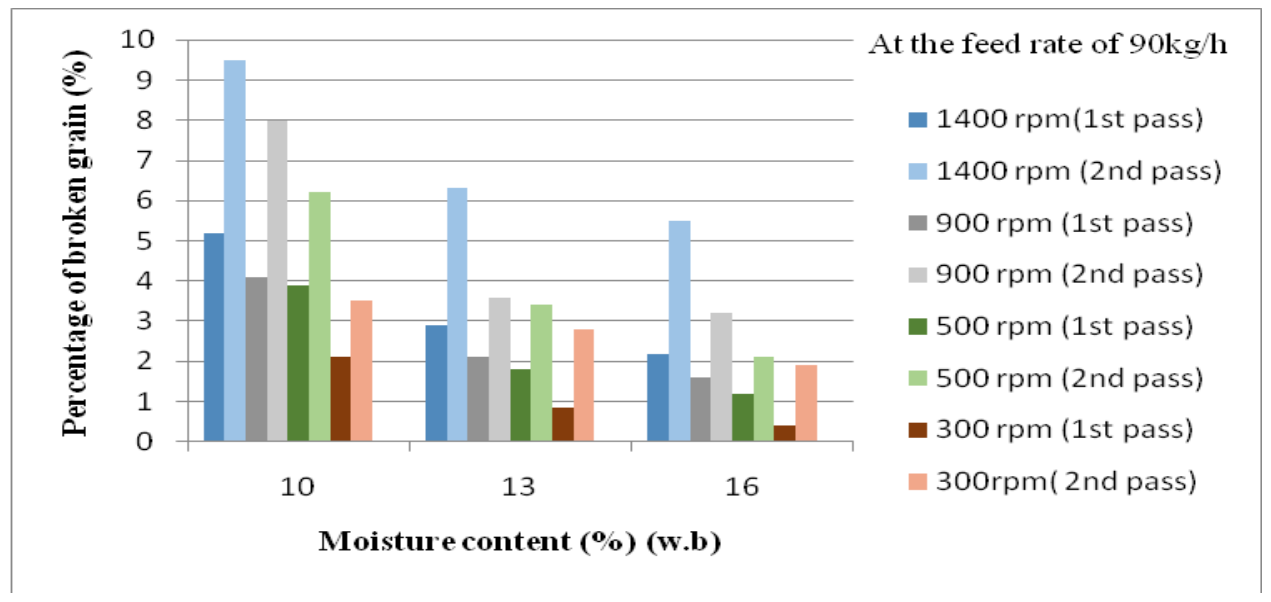

Fig.8 Variation of percentage of broken grain with moisture content and speed of cylinder at feed rate of $120 \mathrm{~kg} / \mathrm{h}$

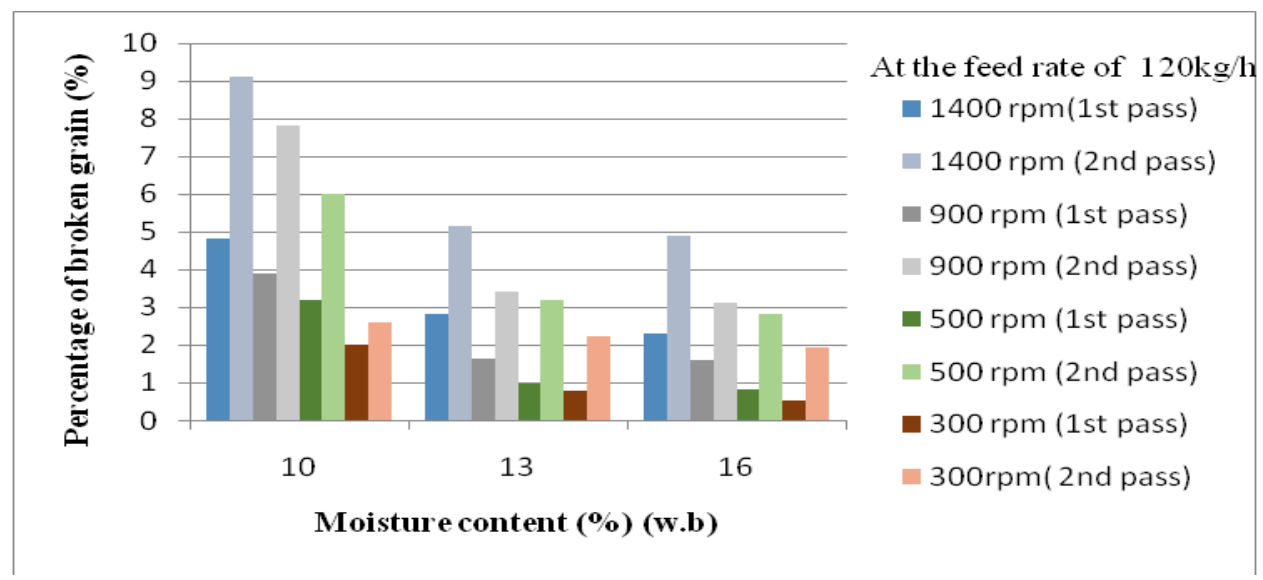

Fig.9 Variation of percentage of broken grain with moisture content and speed of cylinder at feed rate of $150 \mathrm{~kg} / \mathrm{h}$

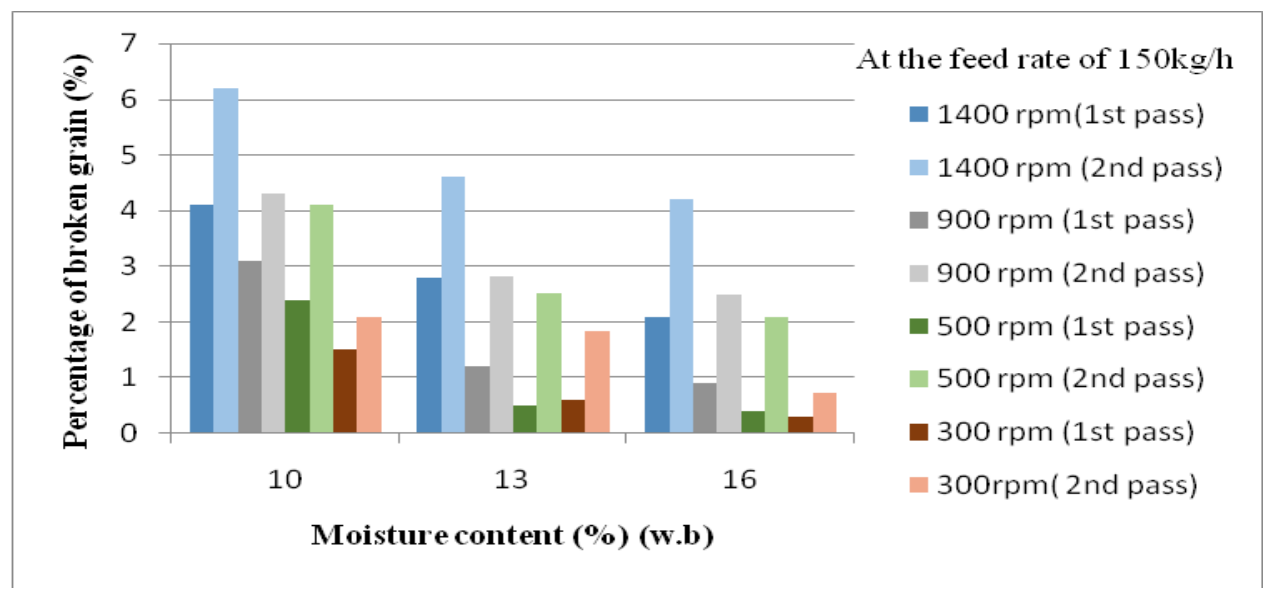




\section{Power operated small scale cleaner cum pearler for finger millet}

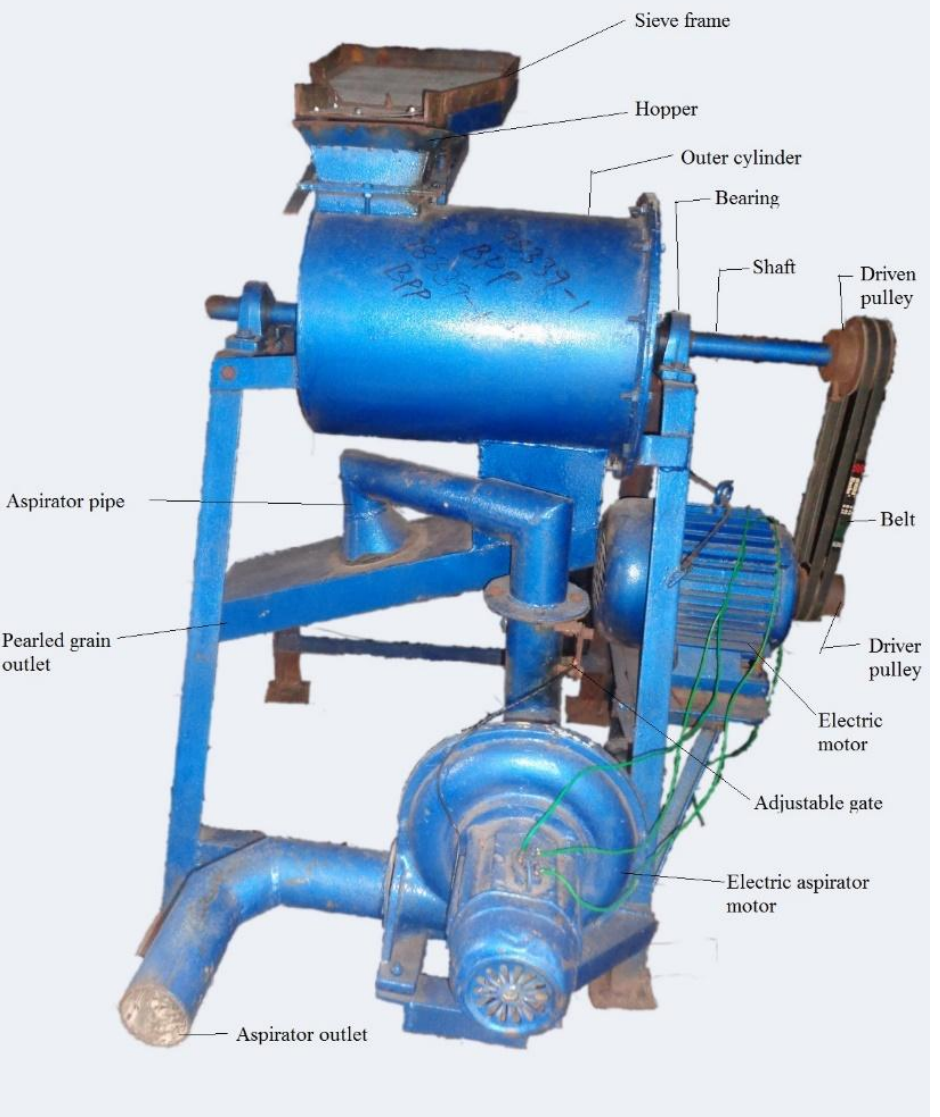

Hence the diameter of the shaft can be obtained as $17.14 \mathrm{~mm}$.

As the shaft is subjected to other speeds also factor of safety 2 can be considered.

Diameter of the shaft $\mathrm{d}=17.14 \times 2=$ $34.28 \mathrm{~mm}$

Hence shaft of diameter $38 \mathrm{~mm}$ was adopted.

\section{Cleaning efficiency}

The average fraction of clean seed at clean seed outlet, fraction of clean seed in feed, fraction of clean seed at aspirator and sieve outlets for all the moisture contents were 0.98 , $0.852,0.0122,0.002$ respectively. Therefore cleaning efficiency can be calculated using the Equation (7).

$\mathrm{E}=0.98 \mathrm{~F}=0.852 \mathrm{G}=0.0122+0.002=$ 0.0142

Cleaning efficiency $(\%)=$ $0.98(0.852-0.0142)(0.98-0.85)(1-0.0142)$ $0.85(0.98-0.0142)^{2}(1-0.85)$

Therefore cleaning efficiency obtained was $88.2 \%$.

\section{Pearling efficiency}

Pearling efficiency of the machine was tested for 1400, 900, 500, $300 \mathrm{rpm}$ speeds, at 10, 13, $16 \%$ (w.b) moisture contents and in two 
passes and. At the feed rate of $90 \mathrm{~kg} / \mathrm{h}$, the pearling efficiency was found to be higher $83.1 \% ; 72 \%$ at $10 \%$ moisture content and $1400 \mathrm{pm}$ in single and double pass respectively. The pearling efficiency decreased with the increase in moisture content. The pearling efficiency was found to be increased with the increase in the cylinder speed. It may be because of higher compression and shearing at high speeds. The pearling efficiency is higher for double pass than single pass. Lower value of pearling efficiency was found to be $52 \%$ at $16 \%$ (w.b) moisture content and 300rpm for single pass.

At the feed rate of $120 \mathrm{~kg} / \mathrm{h}$ the pearling efficiency was found to be higher $85.12 \%$ and $82.15 \%$ at 10, 13\% moisture content respectively. Similar variation with the above feed rate for moisture content and speed was observed.

At the feed rate of $150 \mathrm{~kg} / \mathrm{h}$ the highest value of pearling efficiency $88.4 \%$ was obtained at $10 \%$ moisture content and $1400 \mathrm{rpm}$ for double pass. This may be due to reason that at higher feed rates the clearance between the cylinders is filled completely and maximum shear force can be exerted on all the grains. Lower value of pearling efficiency $56.1 \%$ was observed at $16 \%$ moisture content and $300 \mathrm{rpm}$ for single pass.

\section{Percentage of broken grain}

Percentage of broken grain was obtained for variation all parameters like moisture content, cylinder speed, feed rate. At the feed rate of $90 \mathrm{~kg} / \mathrm{h}$ the highest percentage of broken grain was $9.5 \%$ at $10 \%$ moisture content and $1400 \mathrm{rpm}$ speed for double pass (Fig. 7). At the feed rate of $120 \mathrm{~kg} / \mathrm{h}$, the higher percentage of broken grain was $9.1 \%$ at $10 \%$ moisture content and $1400 \mathrm{rpm}$ for double pass (Fig. 8). At feed rate of $150 \mathrm{~kg} / \mathrm{h}$, the higher percentage of broken was $6.2 \%$ at 10 $\%$ moisture content and $1400 \mathrm{rpm}$ speed for double pass (Fig. 9). This might be due to low force acting on individual grains at higher feed rates.

The machine was fabricated and its performance of was evaluated for pearling efficiency, percentage of broken grain at different feed rates, cylinder speeds and moisture contents in two passes. The cleaning efficiency of the machine was $88.2 \%$. It was observed that as the moisture content of the grains increased the pearling efficiency and the percentage of broken grain decreased. It was observed that at all moisture contents, as the speed of the inner cylinder increases the pearling efficiency was increased and the percentage of broken grains also increased. It was observed that at all moisture contents, as the feed rate increases the pearling efficiency increased but the percentage of broken grain decreased. The highest percentage of broken grain was found to be $9.5 \%$ at $10 \%$ moisture content, $1400 \mathrm{rpm}$ at $90 \mathrm{~kg} / \mathrm{h}$ (II pass). The optimum value of pearling efficiency was $80.1 \%$, broken grain were $4.3 \%$ at $900 \mathrm{rpm}$ speed of cylinder, $150 \mathrm{~kg} / \mathrm{h}$ feed rate, $10 \%$ w.b moisture content (II pass).

\section{References}

AOAC, 2010. Official methods of analysis 18th Edition, Washington D.C.

Audu. I, Oloso A.O. and Bobboi Umar. 2004. Development of a concentric cylinder Locust bean dehuller. CIGR Journal of Scientific Research and Development. 6: 1-11.

Dassannayake. A.S.D.L, Fernandi. A.J, Weerasooriya. G.V.T.V and Bandara. M.H.M.A. 2014. Development of a finger millet threshing, de-husking and cleaning machine. Proceedings of International Symposium on Agriculture and Environment: 161-163. 
Devi. P.B, Vijayabharathi. R, Sathyabama. S, Malleshi. N.G. and Priyadarisini. V.B. 2011. Health benefits of finger millet (Eleusine coracana L.) polyphenols and dietary fiber: a review. Journal of Food Science and Technology. 51(6): 10211040.

Fagbemi. E.A., Iyayi. A.F., Ayeke. P.O., Chimekwene. P.C., Akpaka. P.O., Omonigho B. 2015. Design of dehulling machine for rubber seed processing. Control Theory and Informatics. 4(5): 12-21.

Khurmi. R.S. and Gupta. J.K. A Textbook of Machine Design. Eurasia Publishing House: 120-180, 509-557.

Mathukia. P.R., Sangani. V.P and Mathukia. R.K. 2014. Optimization of roller speed and feed Rate of mini dhal mill for hulling efficiency of pigeonpea. Current Research in Nutrition and Food Science. 2(3):176-181.

Oriaku E.C, Agulanna C.N, Nwannewuihe H.U, Onwukwe M.C and Adiele, I.D. 2014. Design and performance evaluation of a corn de-cobbing and separation machine. American Journal of Engineering Research. 3(6): 127-136.
Ravindra U., Vijayakumari. J., Sharan. S., Raghuprasad K.P. and Kavaloor R.A. 2008. Comparative Study of postharvest processing methods for little millet (Panicum miliare L.) Tropical Agricultural Research. 20: 115 - 122.

Sahay. K.M and Singh. K.K. 1994. Unit Operations of Agricultural Processing. Vikas Publishing house, New Delhi: 70 75, 103-110.

Shittu. S.K. and Ndrika. V.I.O. 2012. Development and performance tests of a melon (egusi) seed shelling machine. Agricultural Engineering InternationalCIGR Journal. 14(1): 1- 12.

Singh. K.P., Mishra. H.N. and Saha. S. 2011. Design, development and evaluation of barnyard millet dehuller. Journal of Agricultural engineering. 48(3): 17-25.

Viswanathan. R., Rajkumar. P, and Kasthuri. R. 2010. Development of a multi-crop pearler and value addition of minor millets to produce breakfast cereals. All India Coordinated Research Project on Post-Harvest Technology, Coimbatore, Investigation No: 2: 9-42.

\section{How to cite this article:}

Tejaswini, V.V., D. Bhaskara Rao, R. Lakshmipathy and Sivala Kumar. 2018. Development and Evaluation of Cleaner cum Pearler for Finger Millet. Int.J.Curr.Microbiol.App.Sci. 7(11): 1819-1830. doi: https://doi.org/10.20546/ijcmas.2018.711.206 